\title{
Efektifitas Model Pembelajaran Inquiry Untuk Meningkatkan Aktivitas dan Hasil Belajar IPS Siswa Kelas VII SMP Negeri 2 Sawan
}

\author{
Faizatun Nisa'1*, Ida Bagus Made Astawa² \\ ${ }^{1}$ Prodi Pendidikan Geografi, Universitas Pendidikan Ganesha, Singaraja, Indonesia \\ 2Prodi Pendidikan Geografi, Universitas Pendidikan Ganesha, Singaraja, Indonesia
}

\author{
A R T I C L EI N F O \\ Article history: \\ Received 18 February 2020 \\ Received in revised form \\ 27 July 2020 \\ Accepted 28 July 2020 \\ Available online 31 August \\ 2020 \\ Kata Kunci: \\ Model pembelajaran \\ inquiry; \\ Akitvitas belajar; \\ Hasil belajar \\ Keywords: \\ Inquiry learning model; \\ Learning activity; \\ Learning outcomes
}

\begin{abstract}
A B S T R A K
Penelitian ini bertujuan menganalisis model pembelajaran Inquiry dalam pembelajaran IPS untuk meningkatkanaktivitas dan hasil belajar siswa kelas VII SMP Negeri 2 Sawan. Penelitian ini adalah penelitian eksperimen dengan pretest-posttest control group desain. Teknik sampling yang digunakanadalah purposive sampling dengan menetapkan 2 kelas yang setara dari delapan kelas, yaitu kelas VII B sebagai kelas eksperimen dan Kelas VII A sebagai kelas kontrol. Pengumpulan data menggunakan metode pencatatan dokumen (data sekunder), observasi (data primer), angket (data aktivitas belajar siswa), dan tes (data hasil belajar siswa). Hasil penelitian menunjukkan bahwa model pembelajaran dapat diimplementasikan guru dengan baik sesuai rancangan pembelajaran yang disusun dengan skor mencapai 73,8 75.9. Pembelajaran dengan model inquiry dapat meningkatkan Aktivitas belajar siswa yang lebih tinggi dibandingkan dengan pembelajaran dengan model ceramah. Hal ini terbukti secara signifikan melalui uji hipotesis dengan thitung $>$ tabel $(1.9174>1.6698)$. Hasil belajar siswa juga
\end{abstract} menunjukkan peningkatan secara signifikan pada kelas eksperimen dibandingkan kelas control. Hal ini terbukti dari uji hipotesis antara kelas eksperimen dan kelas control yang menunjukkan bahwa thitung lebih besar dari tabel>ttabel $(3.7546>1.6698)$. Berdasarkan temuan tersebut dapat dikemukakan bahwaterdapat peningkatan aktivitas dan hasil belajar siswa dengan menggunakan model pembelajaran Inquiry.

\section{A B S T R A C T}

This study aims to analyze Inquiry model in social learning subject to improve activities and learning outcomes of Grade VII students in SMPN 2 Sawan. This is an experimental research designed with pretest-posttest control group. The sampling technique used was purposive sampling by assigning 2 classes which were reflected to eight classes; VII B as an experimental class and VII A as a control class. The method of data collection used recording documents (secondary data), observations (primary data), questionnaires (student learning activities data), and tests (student learning outcomes data). The result showed this learning model can be implemented by teacher well according to the lesson plan prepared with the score of 73.8 - 75.9. Learning with this inquiry model is better to improve student learning activities than learning with the lecturing model. This was proven significantly through hypothesis testing that shows tcount> ttable (1.9174>1.6698). Student learning outcomes in the experimental class also showed a better significanse improvement than the control class. This statement can be proven by the hypothesis testing between experimental class and control class that the count is greater than the table, (3.7546> 1.6698). Based on these findings, the statement of good improvements gotten in student learning activities and outcomes by using this Inquiry learning model is true. 


\section{Pendahuluan}

Pendidikan merupakan kegiatan yang bertujuan untuk memanusiakan manusia khususnya pada generasi penerus guna perkembangan masyarakat dimasa depan. Jika dikhususkan pada pengertian pembelajaran dalam lingkungan sekolah maka pendidikan menjadi suatu keharusan untuk mengembangkan intelektual siswa pada unsur yang lebih formal yang tujuanya sesuai dengan tuntutan kurikulum. Namun demikian pendidikan juga suatu upaya dalam rangka pembentukan karakter siswa melalui suatu proses pengembangan semua aspek kepribadian manusia, baik mencakup pengetahuan, nilai atau sikap, dan keterampilan (Salam, 2002).

IImu Pengetahuan Sosial (IPS) merupakan salah satu mata pelajaran yang harus ada dalam proses pembelajaran di Sekolah Dasar dan Menengah. IPS merupakan kajian yang memadukan berbagai cabang ilmu sosial seperti geografi, sejarah dan ekonomi serta ilmu sosial lainnya. IPS bertujuan untuk mengembangkan potensi siswa untuk lebih peka terhadap masalah sosial yang terjadi, memiliki sifat mental positif terhadap perbaikan segala ketimpangan yang terjadi, dan terampil mengatasi setiap masalah yang terjadi, baik yang menimpa dirinya sendiri maupun masyarakat.

Undang-undang Nomor 20 Tahun 2003 tentang Sistem Pendidikan Nasional menyatakan peserta didik adalah anggota masyarakat yang berusaha mengembangkan potensi diri melalui proses pembelajaran yang tersedia pada jalur, jenjang, dan jenis pendidikan tertentu. Proses pembelajaran bukan sekedar menjelaskan materi pelajaran dan memberikan soal-soal, tetapi ada proses yang melibatkan siswa untuk aktif dalam berpikir rasional mengenai materi yang disampaikan. Oleh karena itu, peran guru sangat penting dalam mempersiapkan model pembelajaran yang tepat untuk diterapkan. Tujuannya, agar siswa memperoleh pengetahuan serta pengalaman dari proses pembelajaran sesuai dengan kemampuan dan perkembangan usia siswa.

Kesiapan guru terhadap materi pembelajaran dan pemilihan model pembelajaran yang akan digunakan merupakan hal yang utama, karena kreatifitas guru dalam menyampaikan materi yang menentukan perkembangan siswa. Ada empat hal yang mendukung perubahan siswa, yaitu: (1) memiliki kemauan dan kesiapan untuk belajar. Hal ini berkaitan dengan niat dan motivasi siswa; (2) adanya keinginan untuk berprestasi.Hal ini berkaitan dengan semangat dan etos belajar siswa; (3) memiliki kemampuan dan tradisi intelektual positif yang berkaitan dengan kecerdasan, sikap, dan perilaku dalam belajar, dan 4) berusaha menciptakan suasana belajar yang kondusif, yang berhubungan dengan kondisi fisik dan psikis (Astawa dan Adnyana, 2018).

Pentingnya penggunaan model pembelajaran yang tepat akan membantu pencapaian hasil belajar yang baik. Apabila model pembelajaran yang digunakan guru tepat dalam mengajar, maka pencapaian tujuan pembelajaran akan lebih efektif (Pupuh dan Sobry S, 2010). Model pembelajaran Inquiry merupakan salah satu langkah yang dapat diimplementasikan dalam proses pembelajaran untuk memperbaiki dan meningkatkan prestasi belajar siswa. Model pembelajaran Inquiry merupakan rangkaian kegiatan pembelajaran yang menekankan pola pikir siswa untuk berpikir secara kritis dan analitis, mencari dan menemukan sendiri jawaban dari suatu masalah yang dipertanyakan (Sanjaya, 2013).

Model pembelajaran Inquiry merupakan salah satu langkah yang dapat diimplementasikan dalam proses pembelajaran untuk memperbaiki dan meningkatkan prestasi belajar siswa. Model pembelajaran Inquiry merupakan rangkaian kegiatan pembelajaran yang menekankan pola pikir siswa untuk berpikir secara kritis dan analitis, mencari dan menemukan sendiri jawaban dari suatu masalah yang dipertanyakan (Sanjaya, 2013:191). Model pembelajaran Inquiry adalah proses pembelajaran lebih menekankan siswa untuk aktif dan merubah tingkah laku siswa berdasarkan pengalaman yang diperoleh secara langsung atau tidak langsung. Dengan menerapkan model pembelajaran Inquiry dapat merangsang keingintahuan siswa sehingga siswa akan lebih memiliki keterampilan berbicara dan mengemukakan pendapatnya, karena yang sangat diperlukan dalam proses pembelajaran adalah pengetahuan dan keterampilan, bukan dari hasil mengingat atau menghafal melainkan melalui menemukan sendiri dengan pengamatan, percobaan dan eksplorasi. Model ini sangat tepat untuk meingkatkan aktivitas belajar mengajar.

Pelajaran IPS di SD (Sekolah Dasar) dan SMP (Sekolah Menengah Pertama) mencakup pengetahuan sosial yang berintikan Geografi.Pelajaran IPS juga diberikan di SMP Negeri 2 Sawan, namun hasil pembelajarannya masih sangat rendah, dengan persentase jumlah siswa mencapai $87 \%$ yang belum mencapai ketuntasan pembelajaran. Hal ini disebabkan proses pembelajaran IPS di kelas VII SMP Negeri 2 Sawan kurang efektif. Guru hanya menjelaskan materi sementara siswa mendengarkan penjelasan dari guru. Selain itu, guru tidak mengimplementasikan model pembelajaran yang relevan, sehingga menjadi salah satu faktor yang mempengaruhi tinggi rendahnya hasil belajar siswa. Ketidak-aktifan siswa di kelas dan rendahnya penguasaan materi disebabkan olehketidak serius siswa mengikuti pelajaran, ada siswa yang hanya diam, bermain sendiri dan bahkan berbicara dengan teman sebangkunya, tidak ada diskusi yang terjadi dalam kelas. 
Proses belajar mengajar di kelas VII SMP Negeri 2 Sawan masih terpusat pada guru, sehingga keterlibatan siswa dalam proses belajar itu masih sangat minim. Kondisi yang dialami dalam proses pembelajaran IPS di kelas VII SMP Negeri 2 Sawan menyebabkan siswa kurang mandiri dalam belajar bahkan cendurung pasif. Akibatnya hasil belajar siswa rendah.

Untuk mengatasi permasalahan tersebut diperlukan adanya upaya untuk memperbaiki kualitas belajar mengajar agar dapat meningkatkan hasil belajar siswa yang lebih baik. Salah satu alternatif yang dapat diterapkan dalam pembelajaran IPS adalah melalui pengimplementasian model pembelajaran Inquiry yang memberikan kesempatan kepada siswa untuk aktif terlibat secara mental, intelektual dan emosional, sehingga siswa akan mendapatkan pengalaman belajar secara maksimal.

Kajian penelitian yang serupa telah dilakukan oleh Agus Suwarno (2016) yang membahas tentang Penerapan Metode Inquiry Terhadap Hasil Belajar Siswa Pada Mata Pelajaran IPS Terpadu Dalam Materi Keragaman Flora Dan Fauna Di Indonesia Di Kelas VII SMP Negeri 1 Tebas. Kemudian penelitian dariDasmaria Sianipar (2016) yang membahas tentang Implementasi metode pembelajaran Inquiry dalam meningkatkan hasil belajar siswa kelas VI SD Negeri 163087 Tebing Tinggi.Penelitian yang telah dilakukan memiliki beberapa perbedaan, walau sama-sama menerapkan model pembelajaran Inquiry.Penelitian ini bertujuan untuk menganalisis bagaimana model pembelajaran Inquiry diimplentasikan dalam meningkatkan aktivitas dan hasil belajar siswa pada mata pelajaran IPS di kelas VII SMP Negeri 2 Sawan.

\section{Metode Penelitian}

Penelitian ini didesain sebagai penelitian eksperimen dengan Pretest-Posttest Control Group Design untuk mengkaji keefektifan proses belajar mengajar melalui model pembelajaran Inquiry dalam meningkatkan aktivitas dan hasil belajar IPS siswa. Subjek penelitian adalah siswa Kelas VII SMP N 2 Sawan yang terdiri dari 8kelas dengan jumlah siswa 255 (rata-rata perkelas terdiridari 32 siswa) beserta guru IPS-nya. Sampel ditentukan secara purposive, kelas VII B dan kelas VII C yang masing-masing kelas berjumlah 32 orang siswa. Kelas VII B sebagai kelas experiment dan Kelas VII C sebagai kelas kontrol. Kelas eksperimen akan diberikan perlakuan model pembelajaran Inquiry, sementara pada kelas kontrol tidak diberikan perlakuan tersebut. Secara sederhana desainpenelitian dapat dilihat pada Tabel 1.

Tabel 1

Desain Penelitian

\begin{tabular}{cccc}
\hline Kelompok & Pre-Test & Perlakuan (x) & Post-test \\
\hline E & $\mathrm{O}_{1}$ & $\mathrm{X}$ & $\mathrm{O}_{2}$ \\
K & $\mathrm{O}_{3}$ & - & $\mathrm{O}_{4}$ \\
\hline
\end{tabular}

$\begin{array}{ll}\text { Keterangan } & : \\ \mathrm{E} & : \text { Kelompok Eksperimen } \\ \mathrm{K} & : \text { Kelompok Kontrol } \\ \mathrm{O}_{1} & : \text { Hasil pre-test Kelompok Eksperimen } \\ \mathrm{O}_{2} & : \text { Hasil post-test Kelompok Eksperimen } \\ \mathrm{O}_{3} & : \text { Hasil pre-test Kelompok Kontrol } \\ \mathrm{O}_{4} & : \text { Hasil post-test Kelompok Kontrol } \\ \mathrm{X} & : \text { Perlakuan }\end{array}$

Data yang dibutuhkan dalam penelitian ini adalah data primer yang meliputi data pelaksanaan model pembelajaran inquiry, aktivitas belajar, dan hasil belajar. Data sekunder meliputi data tentang jumlah siswa yang akan dijadikan subjek penelitian. Berkenaan dengan itu, metode pengumpulan data yang dinilai relevan adalah pencatatan dokumen, observasi, angket, dan tes. Analisis data dilakukan secara deskriptif kuantitatif dengan teknik pengolahan data untuk mendapatkan data dari setiap variabel yang telah ditentukan. Penelitian ini adalah penelitian eksperimen dengan Pretest-Posttest Control Group Design. Teknik analisis data dilakukan uji normalitas dan homogenitas sebagai prasyarat, selanjutnya dilakukan uji hipotesis menggunakan statistic parametric dengan t-test. membuktikan pengaruh model pembelajaran Inquiry efektif dalam meningkatkan aktivitas dan hasil belajar siswa. 


\section{Hasil dan pembahasan}

\section{1) Hasil Penelitian}

a. Implementasi Model Pembelajaran Inquiry

Penilaian terhadap pelaksanaan model pembelajaran yang diimplementasikan guru menggunakan APKCG (Alat Penilaian Keterampilan Calon Guru) Undiksha yang sudah dimodifikasi. Hasil penelitian di kelas Eksperimen menunjukkan bahwa untuk pengamat I dan II skor yang diperoleh adalah sebesar 76.9, dan pengamat III skor yang diperoleh adalah sebesar 73.85. Dari skor yang diberikan oleh ketiga pengamat tersebut, rata-rata yang diperoleh untuk kelas eksperimen adalah sebesar 75.9. Sementara untuk kelas kontrol, untuk pengamat I skor yang diperoleh adalah sebesar 75.4, untuk pengamat II skor yang diperoleh sebesar 73.8 dan untuk pengamat III skor yang diperoleh adalah sebesar 72.3. Dengan demikian rata-rata yang diperoleh untuk kelas kontrol adalah sebesar 73.8. Hal ini menunjukkan bahwa model pembelajaran yang direncanakan dalam Rencana Pelaksanaan Pembelajaran (RPP) telah mampu diimplementasikan dalam suatu pembelajaran di kelas. Skor yang diperoleh antara kelas kontrol dan kelas eksperimen tidak jauh berbeda dan tergolong pada kategori baik dengan perolehan skor 73,8 - 75.9 .

\section{b. Aktivitas Belajar Siswa}

Aktivitas belajar merupakan segala sesuatu yang dilakukan siswa atau kegiatan-kegiatan yang melibatkan interaksi antar guru dengan siswa maupun antar siswa dengan siswa.Instrumen yang digunakan untuk mengukur aktivitas belajar siswa adalah angket. Hasil Angket untuk Aktivitas Belajar siswa Kelas VII SMP N 2 Sawan untuk Kelas Eksperimen dapat dilihat pada Tabel 2 dan untuk kelas Kontrol pada Tabel 3.

Tabel 2.

Penyajian Data Hasil Angket Aktivitas Belajar Kelas Eksperimen

\begin{tabular}{|c|c|c|c|c|c|c|c|c|c|}
\hline \multirow{3}{*}{ No. } & \multirow{3}{*}{ Indikator } & \multicolumn{6}{|c|}{ Kategori } & \multicolumn{2}{|c|}{ Total } \\
\hline & & \multicolumn{2}{|c|}{ Tinggi } & \multicolumn{2}{|c|}{ Sedang } & \multicolumn{2}{|c|}{ Rendah } & \multirow[b]{2}{*}{$\mathbf{N}$} & \multirow[b]{2}{*}{$\%$} \\
\hline & & $\mathbf{N}$ & $\%$ & $\mathbf{N}$ & $\%$ & $\mathbf{N}$ & $\%$ & & \\
\hline 1 & Mengamati objek yang ditunjukkan & 24 & 75 & 8 & 25 & - & - & 32 & 100 \\
\hline 2 & Mendengarkan penjelasan & 20 & 63 & 10 & 31 & 2 & 6 & 32 & 100 \\
\hline 3 & Mengajukan pertanyaan & 23 & 72 & 9 & 28 & - & - & 32 & 100 \\
\hline 4 & Menjawab pertanyaan & 22 & 69 & 10 & 31 & - & - & 32 & 100 \\
\hline 5 & Berdiskusi & 20 & 63 & 9 & 28 & 3 & 9 & 32 & 100 \\
\hline 6 & $\begin{array}{l}\text { Mengemukakan jawaban sementara } \\
\text { mengenai permasalahan yang dikaji }\end{array}$ & 22 & 69 & 6 & 19 & 4 & 12 & 32 & 100 \\
\hline 7 & Membaca, mengamati dan bertanya & 24 & 75 & 8 & 25 & - & - & 32 & 100 \\
\hline 8 & Mengemukakan pendapat & 26 & 81 & 6 & 19 & - & - & 32 & 100 \\
\hline 9 & Bekerja sama & 25 & 78 & 7 & 22 & - & - & 32 & 100 \\
\hline 10 & Meneliti, membuat catatan & 23 & 72 & 7 & 22 & 2 & 6 & 32 & 100 \\
\hline 11 & Analisis data, & 22 & 69 & 8 & 25 & 2 & 6 & 32 & 100 \\
\hline \multirow[t]{2}{*}{12} & Mengemukakan hasil penemuan & 25 & 78 & 7 & 22 & - & - & 32 & 100 \\
\hline & JUMLAH & 276 & 72 & 95 & 25 & 13 & 3 & 384 & 100 \\
\hline
\end{tabular}

Sumber: hasil pengolahan data primer

Berdasarkan Tabel 2 dapat dikemukakan bahwa aktivitas belajar pada kelas eksperimen didominasi oleh kategori tinggi (72\%).Sedangkan persentase yang paling rendah adalah untuk kategori rendah (3\%).Jika memperhatikan masing-masing indikator, aktivitas belajar di kelas eksperimen secara konsisten didominasi pada kategori tinggi. Jadi dengan demikian dapat dikemukakan bahwa proses pembelajaran yang menggunakan model Inquiry dapat membangun pola pikir siswa untuk aktif dan kritis sehingga aktivitas belajar siswa menjadi terkategori tinggi. 
Tabel 3.

Penyajian Data Hasil Angket Aktivitas Belajar Kelas Kontrol

\begin{tabular}{|c|c|c|c|c|c|c|c|c|c|}
\hline \multirow{3}{*}{ No. } & \multirow{3}{*}{ Indikator } & \multicolumn{6}{|c|}{ Kategori } & \multirow{2}{*}{\multicolumn{2}{|c|}{ Total }} \\
\hline & & \multicolumn{2}{|c|}{ Tinggi } & \multicolumn{2}{|c|}{ Sedang } & \multicolumn{2}{|c|}{ Rendah } & & \\
\hline & & $\mathrm{N}$ & $\%$ & $\mathrm{~N}$ & $\%$ & $\mathrm{~N}$ & $\%$ & \multicolumn{2}{|c|}{$\mathrm{N} \%$} \\
\hline 1 & Mengamati objek yang ditunjukkan & 20 & 63 & 8 & 25 & 4 & 12 & 32 & 100 \\
\hline 2 & Mendengarkan penjelasan & 18 & 56 & 9 & 28 & 5 & 16 & 32 & 100 \\
\hline 3 & Mengajukan pertanyaan & 16 & 50 & 9 & 28 & 7 & 22 & 32 & 100 \\
\hline 4 & Menjawab pertanyaan & 18 & 56 & 11 & 35 & 3 & 9 & 32 & 100 \\
\hline 5 & Berdiskusi & 14 & 44 & 12 & 37 & 6 & 19 & 32 & 100 \\
\hline 6 & $\begin{array}{l}\text { Mengemukakan jawaban sementara } \\
\text { mengenai permasalahan yang dikaji }\end{array}$ & 9 & 28 & 13 & 41 & 10 & 31 & 32 & 100 \\
\hline 7 & Membaca, mengamati dan bertanya & 20 & 63 & 8 & 25 & 4 & 12 & 32 & 100 \\
\hline 8 & Mengemukakan pendapat & 19 & 59 & 7 & 22 & 6 & 19 & 32 & 100 \\
\hline 9 & Bekerja sama & 19 & 59 & 8 & 25 & 5 & 16 & 32 & 100 \\
\hline 10 & Meneliti, membuat catatan & 20 & 63 & 10 & 31 & 2 & 6 & 32 & 100 \\
\hline 11 & Analisis data, & 18 & 56 & 8 & 25 & 6 & 19 & 32 & 100 \\
\hline \multirow[t]{2}{*}{12} & Mengemukakan hasil penemuan & 19 & 59 & 7 & 22 & 6 & 19 & 32 & 100 \\
\hline & JUMLAH & 210 & 55 & 110 & 29 & 64 & 16 & 384 & 100 \\
\hline
\end{tabular}

Sumber: hasil pengolahan data primer

Berdasarkan Tabel 3 dapat dikemukakan bahwa aktivitas belajar siswa pada kelas kontrol menunjukkan untuk kategori tinggi mencapai 55\%.Sedangkan aktivitas belajar siswa untuk kategori rendah adalah sebesar $16 \%$. Hasil yang diperoleh di kelas kontrol juga dominan pada kategori tinggi, namun aktivitas belajar siswa yang terkategori di kelas kontrol cenderung lebih rendah dibandingkan dengan kelas eksperimen.Jika dilihat dari masing-masing indikator, aktivitas siswa pada kelas kontrol dengan kategori tinggi yang dominan terdapat pada aktivitas mengamati objek yang ditunjukkan, membaca, mengamati dan bertanya, dan meneliti, membuat catatan.

Berdasarkan uraian antara kelas kontrol dengan kelas eksperimen dapat dikemukakan bahwa aktivitas belajar siswa pada kelas eksperimen lebih tinggi dari pada kelas kontrol.Hal tersebut menunjukkan bahwa model pembelajaran Inquirydalam meningkatkan aktivitas belajar siswa lebih unggul dibandingkan model pembelajaran non inquiry.

\section{c. Hasil Belajar Siswa}

Hasil belajar merupakan gambaran dari penguasaan siswa terhadap pelajaran yang telah diberikan dan menjadi upaya pengukuran kualitas siswa dalam mengikuti sebuah proses pembelajaran. Hasil belajar siswa diperoleh dari pelaksanaan pre-test dan post-test yang diberikan pada kelas kontrol maupun kelas eksperimen.Data hasil pre-test dan post-test dapat di lihat pada Tabel 4.

Tabel 4.

Data hasil belajar siswa kelas eksperimen dan kelas kontrol

\begin{tabular}{|c|c|c|c|c|c|c|c|c|c|}
\hline \multirow{3}{*}{ No } & \multirow{3}{*}{ Keterangan } & \multicolumn{4}{|c|}{ Kelas Eksperimen } & \multicolumn{4}{|c|}{ Kelas Kontrol } \\
\hline & & \multicolumn{2}{|c|}{ Pre Test } & \multicolumn{2}{|c|}{ Post Test } & \multicolumn{2}{|c|}{ Pre Test } & \multicolumn{2}{|c|}{ Post Test } \\
\hline & & $\mathbf{N}$ & $\%$ & $\mathrm{~N}$ & $\%$ & $\mathbf{N}$ & $\%$ & $\mathrm{~N}$ & $\%$ \\
\hline 1 & Tuntas & 13 & 41 & 20 & 63 & 8 & 25 & 10 & 31 \\
\hline \multirow[t]{2}{*}{2} & Tidak Tuntas & 19 & 59 & 12 & 37 & 24 & 75 & 22 & 69 \\
\hline & Jumlah & 32 & 100 & 32 & 100 & 32 & 100 & 32 & 100 \\
\hline
\end{tabular}

Sumber: hasil pengolahan data primer

Berdasarkan Tabel 4 dapat dikemukakan bahwa hasil belajar siswa kelas eksperimen dan kelas kontrol mengalami peningkatan.Ketuntasan yang dicapai di kelas eksperimen mengalami peningkatan 53,84\% sedangkan di kelas kontrol peningkatannya hanya $25 \%$.Siswa yang tidak tuntas di kelas eksperimen mengalami penurunan sebesar $36,84 \%$, sedangkan di kelas kontrol hanya $8,33 \%$. Oleh karena itu pembelajaran model Inquiry lebih dominan dalam meningkatkan hasil belajar siswa kelas VII di SMP Negeri 2 Sawan. Hal ini karena model pembelajaran inquiryyang terpusat pada siswa ternyata mampu meningkatkan daya pikir siswa untuk 
kritis dan aktif dalam menganalisis dan menemukan jawaban dari permasalahan yang dikaji sehingga pemahaman siswa terhadap materi pelajaran menjadi lebih baik yang pada akhirnya berimplikasi pada hasil belajar siswa.

\section{Pengujian Hipotesis}

Guna membuktikan signifikasi perbedaan hasil belajar dari penerapan model pembelajaran inquiry dan yang tidak menerapkan dilakukan uji statistik.Berkenaan dengan itu terlebih dahulu perlu dilakukan uji normalitas data sebagai persyaratannya.Uji normalitas data dilakukan untuk memperlihatkan bahwa data yang diperoleh melalui sampel benar-benarberdistribusi normal, sehingga perbedaan yang terjadi memang akibat perlakuan bukan perbedaan yang ada pada sampel.Uji normalitas data pada hasil belajar diperoleh $\mathrm{X}^{2}$ hitung $\leq$ $X^{2}$ tabelyakni-9.22 $\leq 11.07$ atau berkualifikasi Normal.Secara sederhanaNormalitas data hasil belajar dapat dilihat pada Tebel 5 .

\section{Tabel 5}

Normalitas Data Hasil Belajar

\begin{tabular}{llllll}
\hline No & Kelas & Variabel & $\boldsymbol{x}^{\mathbf{2}}$ hitung & $\boldsymbol{x}^{\mathbf{2}}$ tabel & Kualifikasi \\
\hline 1 & Eksperimen & Hasil belajar (pre test) & $-9.22 \boldsymbol{x}$ & 11.07 & Normal \\
& \multirow{2}{*}{2} & Hasil belajar(post test) & 8.22 & 11.07 & Normal \\
& \multirow{2}{*}{ Kontrol } & Hasil belajar(pre test) & 6.93 & 11.07 & Normal \\
& & Hasil belajar(post test) & 3.97 & 11.07 & Normal \\
\hline
\end{tabular}

Sumber: hasil pengolahan data primer

Berdasarkan Tabel 5 diperoleh harga Chi-Kuadrat hitung $\left(x^{2}\right.$ hitung $)=-9.22$ kemudian dibandingkan dengan Chi-Kuadrat tabel ( $x^{2}$ tabel) dengan derajat kebebasan (Degree Of Freedom) $=6-1=5$. Jika nilai df adalah 5 dan taraf signifikan adalah 0.05 maka harga $x^{2}$ tabel=11.07; karena $x^{2}$ hitung $\leq x^{2}$ tabelyaitu $-9.22 \leq$ 11.07, maka $\mathrm{H}_{0}$ diterima atau $\mathrm{H}_{1}$ ditolak. Jadi dengn demikian dapat dikatakan bahwa data hasil belajar siswa sebelum perlakuan (Pre Test) kelompok kontrol dan eksperimen berdistribusi normal.

Perhitungan untuk hasil post test diperoleh harga Chi-Kuadrat hitung ( $x^{2}$ hitung) 8.22 kemudian dibandingkan dengan Chi-Kuadrat tabel ( $x^{2}$ tabel) dengan derajat kebebasan (Degree Of Freedom) $=6-1=5$. Jika nilai df adalah 5 dan taraf signifikan adalah 0.05 maka harga $x^{2}$ tabel=11.07; karena $x^{2}$ hitung $\leq x^{2}$ tabelyaitu $8.22 \leq 11.07$, maka $\mathrm{H}_{0}$ diterima atau $\mathrm{H}_{1}$ ditolak. Jadi dengan demikian dapat dikatakan bahwa data hasil belajar siswa setelah perlakuan (Post Test) kelompok kontrol dan eksperimen berdistribusi normal.

Untuk membuktikan model pembelajaran inquiry efektif untuk meningkatkan hasil belajar, maka dilakukan uji homogenitas hasil belajar.Uji homogenitas data hasil belajar diperoleh $F_{\text {hitung }} \leq F_{\text {tabel }}$ yakni $0.961 \leq$ 1.8221 atau homogen.Secara sederhana homogenitas data hasil belajar dapat dilihat pada tabel 6 .

Tabel. 6

Homogenitas data hasil belajar.

\begin{tabular}{llllll}
\hline No & Kelas & Variabel & Varian & $\begin{array}{l}\text { F hitung }=\text { Varian terbesar } \\
\text { Varian terkecil }\end{array}$ & F tabel \\
\hline 2 & Eksperimen & $\begin{array}{l}\text { Hasil belajar } \\
\text { (post test) } \\
\text { Kasil belajar }\end{array}$ & 88.1 & 0.961 & 1.8221 \\
Kontrol & 91.7 & & \\
\hline
\end{tabular}

Sumber: hasil pengolahan data primer

Berdasarkan Uji homogenitas hasil belajar siswa Besarnya $F_{\text {hitung }}=0.961$ kemudian dibandingkan dengan nilai $F_{\text {tabel }}$. Derajat kebebasan $(\mathrm{dk})$ untuk pembilang dan penyebut adalah $32-1=31$ dengan taraf signifikan ( $\boldsymbol{\alpha}$ ) $5 \%$ maka diperoleh $F_{\text {tabel }}=1.8221$. Ketentuannya, bila harga $F_{\text {hitung }}$ lebih kecil atau sama dengan $F_{\text {tabel }}\left(F_{\text {hitung }} \leq\right.$ $\left.F_{\text {tabel}}\right)$, maka $\mathrm{H}_{0}$ diterima dan $\mathrm{H}_{1}$ ditolak sehingga varians dikatakan homogen. Karena nilai $F_{\text {hitung }} \leq F_{\text {tabel }}$ (0.961 $\leq 1.8221)$ maka $\mathrm{H}_{0}$ diterima dan $\mathrm{H}_{1}$ ditolak. Hal ini berarti varians data hasil belajar Pre Test kelompok eksperimen dan kontrol adalah homogen.

Prasyarat untuk pengujian pengaruh model pembelajaran Inquiry efektif untuk meningkatkan aktivitas dan hasil belajar siswa, yaitu normalitas dan homogenitas data sudah terpenuhi. Berkenaan dengan itu langkah selanjutnya adalah pembuktian hipotesis tersebut secara kuantitatif menggunakan polled varians. Hasil uji hipotesis untuk hasil belajar dapat dilihat pada tabel 7 . 
Tabel. 7

Hipotesis data hasil belajar.

\begin{tabular}{llllllll}
\hline No & Kelompok & $\mathbf{N}$ & $\mathbf{D k}$ & $\mathbf{X}$ & $\mathbf{S}^{\mathbf{2}}$ & $\mathbf{T}_{\text {hitung }}$ & $\mathbf{T}_{\text {tabel }}$ \\
\hline 1 & Eksperimen & 32 & 64 & 72.9 & 88.1 & 3.754656 & 1.6698 \\
2 & Kontrol & 32 & & 64.0 & 91.7 & & \\
\hline
\end{tabular}

Sumber: hasil pengolahan data primer

Berdasarkan hasil perhitungan hipotesis hasil belajar menunjukkan bahwa koefisien thitung yang diperoleh adalah sebesar 3.754656. Kriteria pengujian adalah, tolak $\mathrm{H}_{0}$ jika $t_{\text {hitung }}>\mathrm{t}_{\text {tabel. }}$ Pada derajat kebebasan $(\mathrm{dk}) \mathrm{n}_{1+} \mathrm{n}_{2}$ - 2 dan ( $\boldsymbol{\alpha}$ ) 5\%), t tabel adalah 1.6698 Berarti $t_{\text {hitung }}>t_{\text {tabel }}\left(3.754656>1.6698\right.$ ) sehingga $H_{0}$ ditolak dan $H_{1}$ diterima.Jadi dengan demikian dapat dikemukakan bahwa model pembelajaran inquiry efektif untuk meningkatkan aktivitas dan hasil belajar siswa.

\section{a. Pembahasan}

\section{b. Implementasi Model Pembelajaran Inquiry}

Model pembelajaran Inquiry merupakan rangkaian kegiatan pembelajaran yang menekankan pada proses berpikir kritis dan analitis untuk mencari dan menemukan sendiri jawaban yang sudah pasti dari suatu masalah yang dipertanyakan, Sanjaya (2013). Pembelajaran merupakan usaha sadar dalam proses interaksi antara siswa dan guru untuk mencapai suatu tujuan yaitu hasil belajar siswa yang lebih baik.

Berdasarkan data yang diperoleh dari penilaian APKCG yang berkualifikasi baik (kelas eksperimen ratarata 76.9 dan kelas control rata-rata 73.85), hal ini menunjukkan bahwa guru mengajar di kelas eksperimen dan kontrol dengan baik, namun ada perbedaan pada aktivitas siswa yang diberikan perlakuan dengan yang tidak diberikan perlakuan tersebut. Pada kelas kontrol siswa cenderung hanya mendengarkan penjelasan guru sedangkan pada kelas eksperimen siswa juga aktif bertanya, berpendapat dan berdiskusi dengan guru maupun dengan sesama temannya. Selain itu, terdapat perbedaan aktivitas dan hasil belajar antara kelas eksperimen dan kelas kontrol. Hal ini disebabkan oleh kegiatan guru dan siswa yang berbeda, di kelas eksperimen siswa yang menjadi pusat keaktifan dengan mengembangkan cara berpikir kritis hingga mampu mengutarakan pendapatnya. Sedangkan di kelas kontrol lebih terpacu pada kegiatan guru yang hanya menjelaskan materi, sehingga siswa tidak memiliki kesempatan untuk mengasah pola pikirnya dari pengalaman yang telah diperoleh. Oleh karena itu, model pembelajaran Inquiry guru hanya berperan sebagai fasilitator dan motivator, guru memberikan kebebasan kepada siswa untuk lebih aktif dalam mengembangkan pengalaman yang sudah ada. Implementasi model pembelajaran inquiry merupakan suatu kegiatan pembelajaran yang menekankan proses belajar siswa, untuk mengembangkan pola pikir yang aktif, kreatif dan kritis dalam menemukan hingga memecahkan suatu persalahan. Hal ini menunujukkan bahwa dalam proses pembelajaran itu sendiri tidak hanya belajar namun ada tujuan yang harus dicapai, yaitu mengembangkan siswa aktif dan meningkatkan hasil belajar yg lebih baik.

Hal ini sejalan dengan penelitian Pratiwi, Sarwi dan Handayani (2012) dalam penelitiannya tentang efektivitas model pembelajaran inquiry terbimbing untuk meningkatkan penguasaan konsep dan kerja siswa. Hasil penelitian ini menunjukkan bahwa Guided Inquiry sebagai pendekatan yang berpusat pada siswa yang berpengaruh positif terhadap keberhasilan siswa dan mengembangkan keterampilan proses ilmiah serta sikap ilmiah mereka.

Hasil penelitian serupa lainnya dilakukan oleh penelitiannya Meja, Mince Tonda (2017) tentang penerapan model pembelajaran inquiry untuk meningkatkan hasil belajar. Penelitian ini menunjukkan bahwa peningkatan proses pembelajaran dapat terlihat dari antusias siswa yang lebih aktif dengan menerapkan model pembelajaran Inquiry yang menempatkan guru hanya sebagai fasilitator.

Hasil penelitian serupa lainnya dilakukan oleh Hana, dkk (2012) bahwa hasil penelitian ini menunjukkakn model pembelajaran inquiry mengajak siswa untuk berfikir konstruktif, dengan demikian siswa dapat memahami konsep atau prinsip memalui temuannya sendiri, oleh karena itu model pembelajaran inquiry efektif untuk diimplementasikan dalam proses pembelajaran.

Penelitian serupa lainnya dikemukakan oleh Ulansari, Ansori dan Yennita (2018:32) bahwa pembelajaran dengan menggunakan model pembelajaran Inquiry mampu memberikan pengalaman belajar secara langsung dan dapat melakukan percobaan secara mandiri mencapai ketuntasan dengan nilai $85 \%$. Melalui pengalaman dan percobaan siswa mampu mengolah daya pikirnya untuk mendapatkan suatu jawaban dari permasalahan yang ada. Hal ini menunjukkan bahwa model pembelajaran inquiry efektif diimplementasikan dalam pembelajaran dan mampu meningkatkan cara berpikir kritis siswa. Pembelajaran dengan menggunakan model inquiry dapat menjadikan siswa lebih aktif dan mandiri untuk menemukan suatu masalah hingga 
pemecahannya. Sehingga disimpulkan bahwa dalam penelitian ini model pembelajaran inquiry efektif diimplementasikan di kelas VII SMP Negeri 2 Sawan.

\section{c. Aktivitas Belajar}

Aktivitas belajar merupakan kegiatan yang menghasilkan berbagai pengetahuan, nilai/sikap, dan keterampilan, sebagai latihan yang dilaksanakan dengan sengaja, Hasmiati, dkk (2017). Aktivitas belajar merupakan serangkaian kegiatan belajar mengajar yang melibatkan guru dan siswa untuk menghasilkan perubahan-perubahan (pengetahuan, nilai/sikap, keterampilan) pada siswa sesuai dengan tuntutan kurikulum. Kegiatan yang terjadi dalam aktivitas belajar ini menuntut siswa untuk aktif secara fisik dan mental dengan tujuan mencapai perubahan-perubahan, baik dari aspek kognitif, afektif maupun psikomotor.

Hasil penelitian di kelas VII SMP Negeri 2 Sawan menunjukkan bahwa terdapat perbedaan aktivitas belajar antara kelas eksperimen yang menggunakan model pembelajaran Inquiry dengan kelas kontrol yang tidak menggunakan model tersebut. Berdasarkan Martias dan Wagino (2018:4) bahwa aktivitas siswa adalah suatu kegiatan yang bersifat fisik atau nonfisik dalam pembelajaran yang melibatkan intelektual-emosional. Hasil uji hipotesis untuk skor angket aktivitas belajar antara kelas eksperimen dan kelas kontrol nilai thitung lebih besar dibandingkan nilai tabel yakni $(1.9174>1.6698)$ hal ini menunjukkan bahwa ada perbedaan aktivitas belajar siswa antara kelas eksperimen yang menggunakan model pembelajaran Inquiry dengan kelas kontrol yang tidak menggunakan model pembelajaran tersebut. AKtivitas belajar di kelas eksperimen lebih tinggi dengan menggunakan model pembelajaran inquiry, hal ini disebabkan oleh kegiatan di dalam kelas yang melibatkan siswa sepenuhnya dalam prosesnya pembelajaran. proses pembelajaran yang efektif mampu membuat siswa aktif dalam berpikir kritis, berpendapat dan hingga menjawab permasalahan yang ada.

Hal ini juga sejalan dengan penelitian yang dilakukan Prasetyo dan Widjanarko (2015:85) bahwa aktivitas belajar siswa dengan menggunakan model pembelajaran Inquiry mengalami peningkatan 84,38\% dengan kategori baik. Demikian juga dengan penelitian yang dilakukan Nurmayani, Doyan, dan Verawati (2018:27) bahwa model pembelajaran Inquiry menempatkan siswa untuk terlibat aktif dalam pembelajaran, keterlibatan aktif siswa menjadikan belajar yang lebih bermakna, karena tidak hanya belajar dengan cara menghafal akan tetapi membangun dan memahami konsep itu sendiri.

Penelitian sejalan lainnya juga dilakukan oleh Setiasih, dkk (2016) bahwa keaktifan, kerjasama dan memecahkan masalah mengalami peningkatan pada setiap siklusnya, hingga mencapai target yang telah ditentukan yaitu $85 \%$ siswa masuk pada kategori sangat baik. Hal ini menunjukkan bahwa dengan model pembelajaran inquiry mampu meningkatkan aktivitas belajar siswa.

Berdasarkan hasil analisis yang dilakukan tersebut, menunjukkan bahwa melalui model pembelajaran Inquiry siswa mampu aktif mengikuti proses belajar mengajar. Seperti yang telah dikemukakan dalam kajian pustaka dan dari penelitian yang sejalan bahwa model pembelajaran Inquiry merupakan pembelajaran yang menekankan keaktifan siswa, melalui model ini guru hanya sebagai fasilitator untuk mengarahkan siswa pada suatu permasalahan yang akan dibahas. Sehingga siswa mempunyai peran penuh dalam suatu proses pembelajaran.

\section{d. Hasil Belajar}

Hasil belajar mempunyai peranan penting dalam proses pembelajaran yang mencakup perubahan setelah terjadi proses pembelajaran Hasil belajar menjadi tolak ukur kemampuan siswa dalam menyerap pelajaran yang telah disampaikan guru selama proses pembelajaran berlangsung. prestasi belajar adalah bukti keberhasilan belajar atau kemampuan seorang siswa dalam melakukan kegiatan belajarnya sesuai dengan bobot yang dicapainya, Winkel (dalam Astawa dan Adnyana, 2018).

Hasil penelitian di kelas VII SMP Negeri 2 Sawan menunjukkan bahwa terdapat perbedaan hasil belajar antara kelas eksperimen dan kelas kontrol. Hasil uji hipotesis nilai post test antara kelas eksperimen dan kelas kontrol nilai $t_{\text {hitung }}$ lebih besar dibandingkan nilai $t_{\text {tabel }}(3.754656>1.6698)$. Hal ini menunjukkan bahwa ada perbedaan aktivitas belajar siswa baik dari nilai pre test maupun post test antara kelas eksperimen dengan menggunakan model pembelajaran Inquiry dengan kelas kontrol dengan menggunakan ceramah.

Penelitian ini dilakukan dengan pemberian pre test sebelum perlakukan baik dikelas eksperimen maupun kelas kontrol, tujuannya untuk mengukur seberapa jauh siswa telah memiliki pengetahuan mengenai pelajaran yang akan diikuti. Kemudian diakhir pembelajaran atau setelah perlakuan, dilakukan post test pada kedua kelas yaitu kelas eksperimen dan kelas kontrol, hal ini untuk mengetahui peningkatan pengetahuan yang diperoleh siswa selama proses pembelajaran. sehingga dari hasil post test siswa, diperoleh bahwa peningkatan nilai siswa dikelas eksperimen dengan menggunakan model pembelajaran Inquiry lebih tinggi daripada kelas kontrol dengan menggunakan model konvensional atau ceramah. 
Hal ini sejalan dengan penelitian dari Julisafitri (2017:7) bahwa hasil penelitian yang diperoleh thitung (1.775) $>t_{\text {tabel }}$ (1.6749), bahwa terdapat perbedaan penerapan model Inquiry dengan model konvensional dan dalam penelitian ini terdapat peningkatan hasil belajar siswa dengan menggunakan model pembelajaran inquiry. Penelitian sejalan lainnya dilakukan oleh Rahmawati, dkk (2015) bahwa hasil penelitian menunjukkan rata-rata nilai posttes 85,55 pada kelas eksperimen dengan penerapan model pembelajaran inquiry, sedangkan pada kelas kontrol rata-rata nilai yang diperoleh adalah 65,52 yang menggunakan pembelajaran secara konvensional.

Penelitian sejalan lainnya dilakukan oleh Lindawati (2019) bahwa hasil penelitian dengan menerapkan model pembelajaran inquiry in study IPS dapat meningkatkan hasil belajar siswa. Peningkatan hasil belajar siswa ini terlihat dari meningkatkannya kemampuan siswa dalam mencari jawaban dari suatu masalah memalui berbagai langkah dalam model pembelajaran inquiry. peningkatan hasil belajar siswa dibuktikan dengan meningkatnya persentase hasil tes belajar siswa pada siklus I (74\%) meningkat pada siklus II (91\%).

Penelitian sejalan lainnya juga dilakukan oleh zarisa dan saminan (2017) bahwa hasil penelitia menunjukkan Pembelajaran inkuiri menggunakan mampumeningkatkan hasil belajar siswa pada pertemuan pertama sebesar $19 \%$ dengan $\mathrm{N}$-gain sebesar 0,41 dan tergolong dalam kategori sedang, dan sebesar $13 \%$ pada pertemuan kedua dengan $\mathrm{N}$-gain sebesar 0,36 dan tergolong dalam kategori sedang.

Hal ini menunjukkan bahwa pembelajaran dengan model Inquiry mampu meningkatkan hasil belajar siswa, sebagaimana telah dikemukakan pada kajian pustaka bahwa model pembelajaran Inquiry merupakan model pembelajaran yang berpusat pada siswa. Model pembelajaran ini memberikan kesempatan lebih banyak waktu untuk berpikir, merespon dan belajar secara mandiri untuk menyelesaikan suatu permasalahan.

\section{Simpulan dan Saran}

Berdasarkan hasil penelitian dan pembahasan maka terdapat 3 hal yang dapat disimpulkan yaitu sebagai berikut. Pertama model pembelajaran inquiry efektif diimplementasikan dalam pembelajaran IPS di Kelas VII SMP Negeri 2 Sawan. Kedua terdapat peningkatan aktivitas belajar siswa dengan menggunakan model pembelajaran Inquiry. Ketiga terdapat peningkatan hasil belajar siswa menggunakan model pembelajaran Inquiry. Hal ini menunjukkan bahwa model pembelajaran Inquiry dalam pembelajaran IPS dapat meningkatkan aktivitas dan hasil belajar IPS siswa kelas VII SMP Negeri 2 Sawan

Berdasarkan hasil penelitian yang telah dilakukan, dapat dikemukakan sejumlah saran:(1) bagi Kepala Sekolah, hasil penelitian ini dapat dijadikan masukkan dalam memaksimalkan implementasi pembelajaran guru-gurunya di kelas dengan model pembelajaran yang relevan, (2) bagi Guru, dapat dijadikanpengalaman dalam mengembangkan bakat siswa melalui proses belajar mengajar yang bermakna, dan (3) bagi peneliti lain, penelitian ini dapat dijadikan referensi dalam melakukan penelitian mengenai penerapan model pembelajaran Inquiry.

\section{Daftar Rujukan}

Astawa, Ida Bagus Made dan Adnyana. 2018. Belajar dan Pembelajaran. Depok: Rajawali Grafindo Persada.

Fathurohman, Pupuh dan M. Sobry Sutikno.2010. Strategi Belajar Mengajar Melalui Penanaman Konsep Umum dan Konsep Islami. Bandung. Refika Aditama.

Hana, Nilul., Syamsu Hadi., Marimin. 2012. Efektivitas Metode Pembelajaran Inkuiri Dengan Metode Pembelajaran Konvensional Untuk Meningkatkan Hasil Belajar Mata Pelajaran IPS Terpadu Pokok Bahasan Permintaan, Penawaran Dan Terbentuknya Harga Pasar Siswa Kelas VIII SMP 2 Bae Kudus. Economic education analyisis journal 1(1)

Hasmiati., Jamilah dan Mustami. 2017. Aktifitas dan Hasil Belajar Siswa Pada Pembelajaran Pertumbuhan dan Perkembangan dengan Metode Praktikum. Jurnal Biotek Vol 5(1).

Julisafitri, Revi. 2017. Pengaruh Model Pembelajaran Inkuiri Terbimbing Terhadap Hasil Belajar Biologi Siswa Pada Materi Jamur Di Kelas X Mia Sma Negeri 7 Kota Jambi. Jurnal Pendidikan Biologi

Lindawati. 2019. Model Pembelajaran Inquiry Untuk Meningkatkan Hasil Belajar IPS Pada Siswa Kelas V SD Negeri 59 Bengkulu Utara. Jurnal Georaflessia Vol 4 No 1.

Martias.Wagino.2018. Penerapan Model Pembelajaran Inquiry Untuk Meningkatkan Keaktifan Dan Prestasi Belajar Siswa Pada Pembelajaran Sistem Pengapian Kelas Xi Tkr Smkn 2 Muara Bungo. Jurnal Jurusan Teknik Otomotif Vol 1(1).

Meja, Mince Tonda. 2017. Penerapan Model Pembelajaran Inkuiri Untuk Meningkatkan Hasil Belajar Siswa Kelas V Sd. Jurnal Pendidikan Guru Sekolah Dasar. 
Nurmayani, Lia., Doyan, Aris., Verawati, Ni nyoman S.P . 2018. Pengaruh model pembelajaran inkuiri terbimbing terhadap hasil belajar fisika peserta didik. Jurnal Penelitian Pendidikan IPA 4(2)

Prasetyo, D.a., Widjanarko, Dwi. 2015. Penerapan Model Pembelajaran Inkuiri Untuk Meningkatkan Hasil Belajar Siswa Pada Kompetensi Memelihara Komponen Sistem Bahan Bakar Bensin. Jurnal Pendidikan Teknik Mesin Vol 15 No 2 (82-86).

Pratiwi, L., Sarwi., Handayani, L. 2012. Efektivitas Model Pembelajaran Eksperimen Inkuiri Terbimbing Berbantuan My Own Dictionary Untuk Meningkatkan Penguasaan Konsep Dan Unjuk Kerja Siswa Smp Rsbi. Unnes Science Education Journal 1(2)

Rahmawati, Hani., Syaodi, Erliany., Lisnawati, Cucu. 2015. Efektivitas Model Pembelajaran Inquiry Untuk Meningkatkan Kemampuan Berpikir Kritis Siswa. Jurnal pendidikan dan pembelajaran ekonomi akuntansi Vol 1 No 1

Salam, Burhanuddin. 2002. Pengantar Pedagogik. Jakarta: PT RINEKA CIPTA.

Sanjaya, Wina. 2013. Perencanaan dan Desain Sistem Pembelajaran. Jakarta: Kencana, Prenada Media Group.

Setiasih, Shanty Della., Panjaitan, Regina Lichteria., Julia. 2016. Penggunaan Model Inkuiri Untuk Meningkatkan Hasil Belajar Siswa Pada Materi Sifat-Sifat Magnet Di Kelas V Sdn Sukajaya Kecamatan Jatinunggal Kabupaten Sumedang. Jurnal Pena IImiah Vol 1 No 1

Sianipar, Dasmaria. 2016. Implementasi Metode Pembelajaran Inquiry Dalam Meningkatkan Hasil Belajar Siswa Kelas VI SD Negeri 163087 Tebing Tinggi. Elementary School Journal PGSD FIP Enimed 6(1)

Suwarno, Agus. 2016. Penerapan Metode Inquiry Terhadap Hasil Belajar Siswa Pada Mata Pelajaran IPS Terpadu Dalam Materi Keragaman Flora dan Fauna di Indonesia di Kelas VII Negeri 1 Tebas. Jurnal IImiah Kependidikan Vol 7 No 1

Ulansari, P.T., Ansori, I., Yennita. 2018. Penerapan Model Pembelajaran Inkuiri Untuk Meningkatkan Aktivitas dan Hasil Belajar Siswa. Jurnal Pendidikan dan Pembelajaran Biologi Vol 4 No 1

UU No. 20 Tahun 2003 Tentang Sistem Pendidikan Nasional.Terdapat pada https://edunamika.com/uu-sistempendidikan-nasional-sisdiknas/diakses pada 05 Maret 2019.

Zarisa, Alfi., Saminan. 2017. Penerapan Pembelajaran Inkuiri Menggunakan Metode pictorial Riddle pada Materi Alat-Alat Optik Untuk meningkatkan Kreativitas dan Hasil Belajar Siswa. Jurnal Pendidikan sains Vol 5 No 1 